\title{
A roadmap to a cure
}

\author{
Mario Stevenson \\ From 17th International Symposium on HIV and Emerging Infectious Diseases (ISHEID) \\ Marseille, France. 23-25 May 2012
}

Highly active anti-retroviral therapy (HAART) effects sustained suppression of viral replication in infected individuals. Despite this, viral replication rapidly resumes if therapy is interrupted. The prevailing view is that viral persistence during HAART is sustained by a reservoir of latently infected, quiescent CD4+ T-lymphocytes, a view that is supported by the apparent lack of viral evolution in the resting CD4+ T cell reservoir and the apparent lack of change in low level plasma viremia when therapy is intensified. A less popular view is that viral persistence in HAART may be sustained by a low level of ongoing or "cryptic" replication, a view that is supported in part by our recent work measuring unintegrated cDNA and specifically episomal cDNA in HAART- treated patients.

In order to characterize the reservoirs that persist in the face of HAART, we have been examining the dynamics of HIV-1 in tissue viral reservoirs and the virologic response to therapy in lymphoid tissue. Lymphoid tissue was obtained from patients at various intervals after HAART initiation and the virologic response as well as intracellular drug levels in cells from lymphoid tissue was examined. Our analysis indicates that suppressive therapy is limited in its ability to curtail HIV-1 replication in lymphoid tissue and that this may be a consequence of poor intracellular sequestration of some antiretrovirals in cells of lymphoid tissue. These results have implications for strategies aimed at limiting viral persistence in the face of HAART.

Published: 25 May 2012

doi:10.1186/1742-4690-9-S1-I11

Cite this article as: Stevenson: A roadmap to a cure. Retrovirology 20129 (Suppl 1):111.

University of Miami, Leonard M. Miller, Miami, USA

Submit your next manuscript to BioMed Central and take full advantage of:

- Convenient online submission

- Thorough peer review

- No space constraints or color figure charges

- Immediate publication on acceptance

- Inclusion in PubMed, CAS, Scopus and Google Scholar

- Research which is freely available for redistribution

Submit your manuscript at www.biomedcentral.com/submit
C Bïomed Central

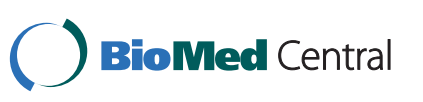

() 2012 Attributionson; licensee BioMed Central Ltd. This is an Open Access article distributed under the terms of the Creative Commons any medium, provided the original work is properly cited. 